\title{
Green-Innovation Value Creation Perspective in Improving Marketing Performance in Palm Oil Plantation Industry
}

\author{
Muhammad Hilman FIKRI ${ }^{1}$, Endang S. RINI ${ }^{2}$, Paham GINTING ${ }^{3}$, Beby K.F. SEMBIRING ${ }^{4}$ \\ ${ }^{1}$ Doctoral Student Department of Management Science, Facukty of Economics and Business, \\ University of Sumatera Utara, Email: m.hilmanfikri@gmail.com \\ ${ }^{2,3}$ Postgraduate Lecturer at the Faculty Economics and Business, University of Sumatera Utara \\ Email: endang.sulistya@usu.ac.id \\ * Corresponding Author
}

Received: 18.11.2021 Accepted: 02.12.2021 $\quad$ Published: 02.02.2022 $\quad$ DOI: 10.47750/QAS/23.186.29

\begin{abstract}
The Green-marketing concept integrates marketing management by saving the environment, which includes reforestation, ecological, and sustainable design and development processes. Therefore, the purpose of implementing green-marketing is to continuously improve the company's performance by complying with environmental regulations. In the progression of the oil palm plantation industry, which is ignoring the appropriate protocols, exclusively for eco-friendly aspects, so that Indonesian CPO products often rejected by consumers. The objective of this research was to determine the factors that influence green-marketing in the oil palm plantation industry. This study used several variables, including green-marketing, positional advantage, green-innovational value creation and marketing performance. This study also added green-innovational value creation to mediate the relationship with green-marketing and marketing performance. The sample in this study was 125 company leaders consisting of Director of Operations, Production Manager and Certification Leaders from 52 companies that have been certified ISO/ISPO. This research was using descriptive analysis and SEM (Structural Equation Model) analysis. This research's results showed that green-marketing gives a substantial effect on increasing marketing performance. Green-marketing has an upright and significant impact on positional advantage. Green-marketing has an upright and substantial effect on increasing green-innovational value creation. Positional advantage has an upright effect on increasing marketing performance. Green-innovational value creation has an upright and substantial impact on marketing performance. In addition, green-innovation value creation mediates the relationship between eco-friendly marketing and increased marketing performance of the Oil Palm Plantation Industry.
\end{abstract}

Keywords: Palm oil, ISO/ISPO, green-marketing, marketing performance, positional advantage, the creation of greeninnovational value.

\section{Introduction}

In the Indonesian economy, a deliberate role is held by the palm oil industry, including the major foreign exchange recipient, the locomotive of the national economy, energy sovereignty, driving the people's economic sector, and employment. Indonesia's oil palm plantations are growing fast and reflect the oil palm revolution. Indonesian oil palm plantations are growing in 22 of the 33 provinces in Indonesia.The two main islands of the oil palm plantations center in Indonesia are Sumatra and Kalimantan. Palm oil is renowned for its versatility in a variety of consumer products including cooking oil, snacks, shampoos, cosmetics and household care products. The sustainability aspect of oil palm plantations is under the spotlight. The development of oil palm plantations in Indonesia is perceived unsustainable and considered the main cause of deforestation and loss of wildlife habitat.

The effect of deforestation is certainly cannot be taken for granted, from the decrease of primary forests (forests that have never been infested by humans), the protected species and biodiversity's extinction, and also global warming. According to Ramadhani and Santoso, (2019) The government needs to improve its marketing strategy by promoting and advocating in the face of the black campaign for Indonesian palm oil. In addition, the government must have strong regulations to use degraded land and reduce the destruction of biodiversity. Indonesia can protect its biodiversity by halting the conversion of natural forests to oil-palm land. In addition, the government does not only focus on crude oil and refined palm oil products, but the government must also diversify palm oil products processing palm oil to the downstream sector.

The possibilities and prospects for oil-palm development in Indonesia specify that oil-palm has prospective projections in the future, especially in terms of further value and competitiveness. Sustainable palm oil is becoming the 'norm', 
consumers should be given the choice to understand that palm oil can be produced in many different ways. Opportunities for the oil-palm plantation industry in Indonesia must strive to improve competitive quality with the aim of achieving maximum economic performance. One of which is determined through the ability in implementing a mix marketing strategy by the company. Various problems that occur become obstacles and challenges in the sustainable advancement of the Indonesian palm oil industry, so clear and firm policies are needed regarding the restrictions and management of oil-palm plantations, so that no more part is harmed.

One pattern that should be done in the development of Indonesian palm oil is applying marketing based on the values of green-innovation. The application of green-innovation and environmental commitment is expected to shape product success. The support of all parties is required for the successful accomplishment of new products with the implementation of green-innovation, especially the commitment efforts of the organization in conserving the natural environment. This is a step taken by stakeholders in the palm oil industry to align the environmental interests and market demands, so that responding to the demanding global challenge of sustainably produced palm oil.

The patron of environmental management as an effective basis for entrepreneurial behavior is entailed by this commitment (Keogh and Polonsky, 1998). Eco-friendly innovation known as green-innovation is an effort made in industry that can conducted in all aspects and developed sustainably along with its development in terms of environmental aspects (Rennings, 2009). The right environmentally friendly innovation activities not only have the ultimate goal in reducing negative impacts on the environment but also have the ultimate goal in increasing the competitive advantage of green products (Porter and Linde, 1995).

The sustainable palm oil industry is defined as an industry that is profitable in business, generates socio-economic benefits for the community and contributes to environmental conservation. Palm oil which is only eco-friendly and not socioeconomically friendly and not business-friendly, will not be sustainable, neither palm oil which is business and socioeconomically friendly nor non-eco-friendly will be sustainable. Supporting this comprehensive improvement in the palm oil industry through innovations derived from continuous research. The entire strategy of the company is always directed to produce these performances, so that the company's performance in this study is only seen from marketing performance, it can be said that it is a construct commonly used to measure the impact of a marketing strategy on marketing performance, such as eco-friendly innovation, product completeness, and competitiveness of eco-friendly products.

\section{Literature Review and Theoretical Background}

In this section there is an explanation of the literature relevant to this research related to the main theoretical basis of this research, green-marketing, green-innovation value creation and position advantage in the background of this research.

\subsection{Resource Competition \\ Advantage Theory of}

This study used the main theoretical basis, namely the Resource Advantage Theory of Competition (RATC). This explains the theories derived from the Resource Advantage
Theory of Competition (RA). The Resource Advantage Theory of Competition emphasizes the importance of resources, both tangible and intangible, to companies that enable efficient and effective production of market offerings that have value for multiple market segments. Competition consists of ongoing activities among companies for comparison to the company's advantage in resources by looking at competitive advantage, position of the market, and superior financial performance (Hunt, 1995).

Competitive advantage in the context of the company, the company's internal resources and capabilities are inputs that allow the company to carry out operational activities and determine the right strategy choices to be able to compete in the modern business environment. The theory of resource advantage is built on errors by focusing on organizational strategy in pursuit of organizational advantage. Resource advantage theory (RA theory) explained that firms can increase their competitive advantage over other competitors through comparative advantage in resources which, in turn, leads to superior financial performance (Hunt \& Morgan, 1996). The customer value is influenced by the way the company manages resources, both tangible and intangible. The way of managing resources is related to the company's orientation in achieving its vision, mission and goals. Green-marketing orientation is a perspective of company leaders at various levels in realizing market competition and expanding market share.

\subsection{Green-marketing}

Green-marketing is one of the essential approaches that business organizations conduct. On the one hand to gain the trust of consumers, the trust of governments and on the other side, the other parties working to preserve the environment. The organization's persistence in the market depends on its pledge to environmental and customer protection standards from the damage that may come from its work (Hersh, et.al, 2015).

Green-marketing is a marketing mix that is different from the traditional marketing mix. Although the indicators remain the same, green-marketing is more of a marketing activity that involves environmental factors as its main orientation. The application of green-marketing has many positive impacts for the company. Some of the impacts of implementing greenmarketing internally are in the form of health, safety, worker safety, increasing comfort when doing work and will have an effect on the effectiveness, productivity and employee's profitability. From an external perspective, it increases consumer loyalty and further improves the quality, safety and friendliness of the products produced. As well as improving the image of the company and playing a role in protecting the environment, both land, water and air.

The purpose of green-marketing is not just to see return as the main objective of the corporation, but a further apprehension for the environment. According to John Grant (2007) in his book titled The Green-marketing Manifesto, he classified the goals of green-marketing into 3 stages, they are:

1. Try to communicate that the label or corporation cares on the environmental preservation as the initial phase for corporations that adopting the concept of greenmarketing.

2. In addition to marketing as the sole objective of the corporation, but also to accomplish targets that impact the environment. The company tried to alter the consumers way to consume and use. For example, paper-saving, paper-waste usage or recycled paper. Water-saving, electricity, use of air conditioning, etc.

3. The corporation is trying to alter the culture of the consumer to be more eco-friendly. The consumer culture 


\section{GENERAL MANAGEMENT}

that expected to be apprehended is concentrated for the surrounding in every action without being influenced by the company's products. The concept of greenmarketing becomes a communication tool for companies to make it an eco-friendly industry in the thoughts of consumers and assists in building relationships between consumers and companies.

\subsection{Positional Advantage}

One conception taken from the resource advantage theory (RA Theory) is called positional advantage. A wide-ranging theory on competition theory that explained the fundamental objective of resource-based approach was to gain a resourcebased comparative benefit which can result in an advantageous position in some segmentations of the market to achieve a firm performance benefit is called RA-Theory based on Hunt and Morgan (1995).

The quality of decisions and application of the company's marketing strategy is determined by marketing resources and capabilities. Moreover, the value of the strategy in marketing will definitely be able to decide the precedence of the corporation's position, and that advantage will decide the performance of financial and marketing (Morgan, 2012). The position advantage discoursed here is the comparative value of the marketing strategy results distributed to the aimed market with the customer's available alternatives. Positional advantages are described in terms of product features, services, prices, costs, image and delivery based on positional advantages (Morgan, 2012). It concentrates on the positioning advantage based on image, namely the religious image of the company which still receives less attention from researchers.

According to Hult and Ketchen (2001) that position advantage has a helpful outcome on company performance. Beside this, the theory of competitive advantage referred to a leading position over other competitors, which come from the capabilities' exploitation based on low-cost predominance and differentiation advantage (Hari \& Wensley, 1988). And continuous performance has been considered in international business as a measure related to the economic value taken from the commercialization of the firm's capabilities (Hult et al., 2008). The sources and talents' alteration into positional advantage has been recognized as the basic "booster" of cost and differentiation advantage (Porter, 1985), and the combination of these creates value to customers. Conceptually, positional advantage is defined as a major advantage in relation to competition through the provision of low-cost or differentiated products (Porter, 1991). Market orientation will allow companies to determine through customer and competitor focus where value can be created in the competitive landscape. However, recently, it has been shown that market orientation is not solely responsible for improved performance.

\subsection{Green-innovation Value Creation}

In an era that gives attention to the environment (ecosystem), ideas to conserve the environment from the companies must be unified. For this objective, green-innovation is very important for enterprise business management. Value can be created by efficient management, take benefit of competitive advantages, and improve company performance
(Chang \& Chen, 2013). Corporate leaders (executives), educational administrators, political leaders and religious leaders all profess to be innovative. In a broad sense, innovation is synonymous with change (Tushman \& O'Reilly, 1997). Changes due to nature, designs that occur from human ingenuity, or individual cooperative efforts (Lee \& Olson, 2010).

Green-innovation Performance (GIP) helps companies achieve greater efficiency as well as build and strengthen their core competencies. Innovation is the main way to reduce or avoid environmental damage. Green technology provides two main benefits to organizations: getting commercial benefits from creating environmentally based products in a sustainable manner, and financial benefits that can increase competitiveness. Customers around the world expect to buy increasingly environmentally friendly products and services. Green-innovation is therefore a strategic need for companies and provides a great opportunity to meet customer demand without damaging the ecosystem.

There is a positive relationship between green-innovation and the availability of jobs, and that the relationship contributes greatly to companies that are often referred to as 'dirty' companies or companies that create waste, this is because companies will feel a greater need to distinguish from companies that are less likely to create waste (clean) to avoid sanctions for not doing green-innovation or to capture green market opportunities. There is also a positive relationship for companies that practice green-innovation based on awareness (voluntary), compared to companies that carry out greeninnovation activities just to comply with regulations. Then there is also a helpful correlation between jobs and companies that always provide information for the improvement of interests implemented for green-innovation (Kunapatarawonga \& Ros, 2016).

\section{Structural Equation Model Partial Least Square (SEM-PLS)}

This research data analysis technique uses Structural Equation Modeling (SEM) with Smart Partial Least Squares (PLS) software with the consideration that the statistical model is quite complicated and intended for knowledge exploration. Partial Least Squares Analysis (PLS) is a multivariate statistical technique that compares multiple dependent variables and double independent variables (Abdillah and Jogiyanto, 2015).

PLS model evaluation was done by assessing the outer model and inner model. A measurement model to speculate the relationship between the estimated indicator or parameter and its concealed variables called the outer model, while the inner model is a structural model to predict.

In research models that use multidimensional constructs, namely constructs formed from dimensional constructs and indicators that form latent dimensional constructs, then testing or analysis was conducted at two levels, namely analysis on First Order Constructs or Lower Order Constructs (latent dimensional constructs that are reflected or formed by its indicators) and analysis on Second Order Constructs or Higher Order Constructs (constructs that are reflected or formed by latent construct dimensions). 


\section{GENERAL MANAGEMENT}

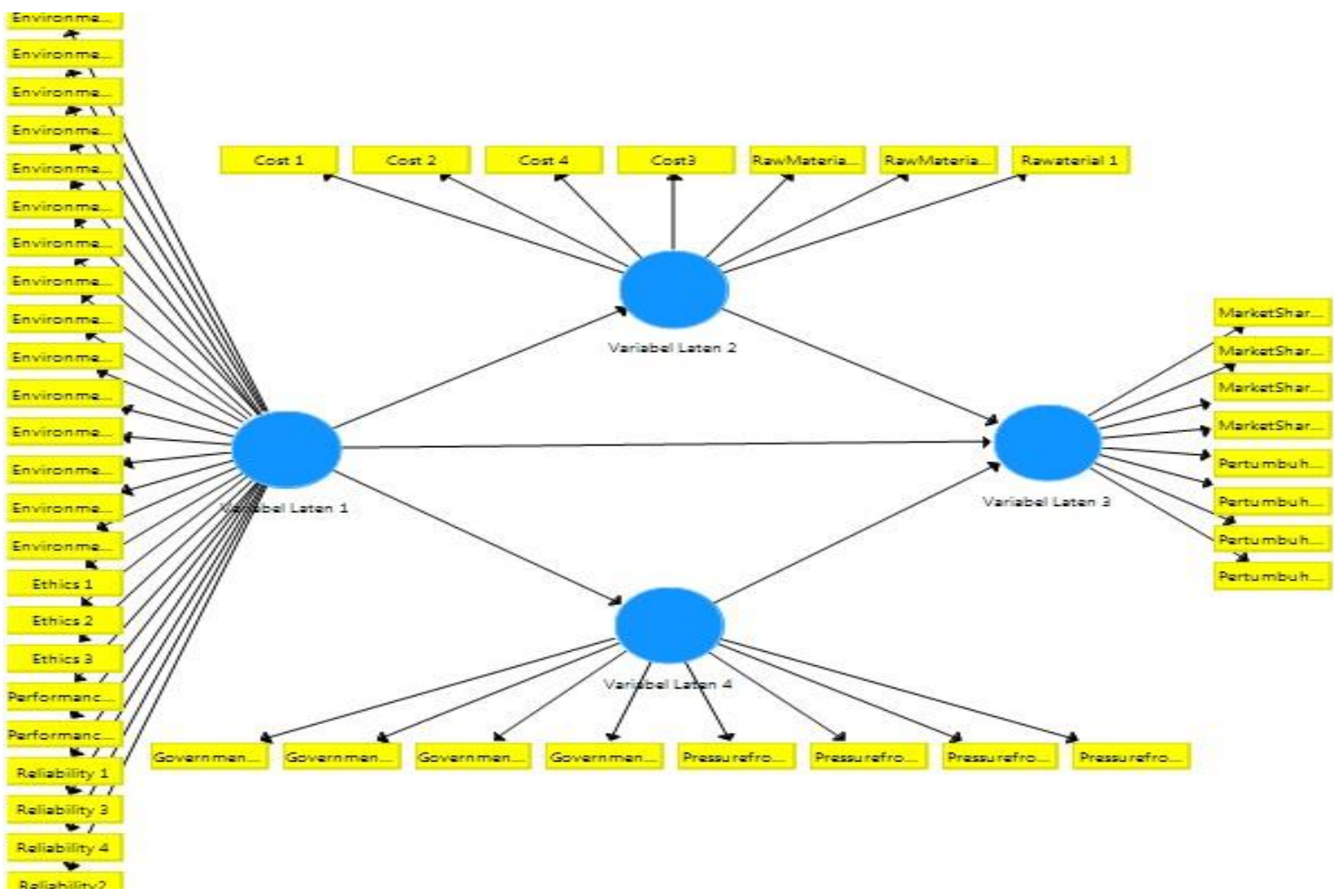

\section{Hypothesis Development}

Company orientation towards Green-marketing application is associated with green companies in the manufacture of products, distribution and stock of products and raw materials and promotional prospects Chen and Chang (2012), Chen (2010), Vaccaro (2009) and Chan and Lau (2000), companies recognize the role of green-marketing and its sustained effect on surroundings (Amegbe, 2017). Green-marketing strategy, business performance, and corporate image, three of them had a supporting relationship which implicated the managerial and policy in the industry (Mukonza and Swarts, 2019), greenmarketing is increasingly being known as specific context along with its own exclusive characteristics (McDonagh \& Prothero, 2019). 2014), which is useful, for constructing a framework that operates different cultural, social, economic and political aspects (Steg \& Vlek, 2009). Environmental impacts occur throughout the life cycle of product, starting from the procurement of raw materials, the manufacturing process, the use of product recycling to the disposal stage (Zhu, Sarkis \& Lai, 2008). The company's operational activities such as green products and processes in the form of development, operations management which tend to be lean and green, and to remanufacturing there are supply chains that tend to be closed (Bai and Sarkis 2010; Corbett and Klassen 2006; Kleindorfer et al. 2005).

The product has three elements that are in fact an effective business tactic, namely awareness, training and the environment (Newman, 1966). Products produced through innovation and promotion through advertising play an important role in the company's success. Starting from information about the product spread by advertising and word of mouth (Kalish, 1985). According to Rajeev (2016) the positive impact of companies implementing green-marketing in the form of positive consumer responses, improving financial performance, providing a respectable reputation of the company in the midst of consumers towards brands, and increasing profits for companies.

Consumer insights of product appeal positively affect product quality perceptions. Consumers who are not wellinformed about a product and when consumers have no previous understanding in using the product, the presentation of the product serves as an extrinsic cue that facilitates consumers' assessment of product quality (Garber et al. 2000). A product that is presented, impacts consumer perceptions on the attractiveness of the products that are not known, but not for products that are already known (Schnurr, 2016).

A firm's positional advantage within the segment of the market which it operates is inferred to be a competitive advantage. This advantaged is created on making a value on the superior customer and also to lower the production cost compared to competitors involved. (Hooley \&Greenley, 2005). The key factors that improved firm performance are position advantages based on costs, promotions, and sales (Hill, 1988). A company's positional advantage is the result of competitive strategy efforts to become a low-cost manufacturer in the industry and/or distinction in product/service lines (Martin, et.al, 2016). Companies that are interested in corporate image and social commitment should conduct positive performance activities. Employee job satisfaction and health and safety measures increase after social performance can be improved; thus, the company always involves and participates in campaigning for the provision of eco-friendly logistics.

There is a solid relation between green-marketing and marketing performance (customer satisfaction, positive impression, organizational reputation), in the Company's industrial process. Product innovation and green-innovation processes have a positive relationship in improving long-term performance and providing a competitive advantage for the company. In this case, the company's commitment is highly expected in terms of efficiency in energy use or reducing waste from production which will improve the company's financial performance (Yao, Zeng, Sheng and Gong, 2019). 


\section{GENERAL MANAGEMENT}

\section{Research Method}

This research was done with explanatory research which the research problems has gone through findings and limitations so that they are applicable and researchable (Zigmund 2000). This research is associative research because it connected and saw the influence of independent variables through mediating variables on the dependent variable either directly or indirectly. In accordance with the desired objectives in this study, namely obtaining the results of Green-marketing and Marketing Performance: 1) Greenmarketing; 2) Positional Advantage; 3) Green-innovation Value Creation; 4) Marketing Performance.

The dimensions used to measure green-marketing are: 1) green product; 2) green promotion; 3) green place; 4) performance; 5) reliability; 6) Ecolabel certificate. The dimensions used to measure positional advantage are: 1) Cost; 2) Differentiation; The dimensions used to measure marketing performance are: 1) Customer growth; 2) Market shares. And the dimensions that measured the value creation of greeninnovation are: 1) governmental pressures; 2) pressure from competitors.

The population of this research was the leaders and person in charge (GM, ADM, Manager) of oil palm plantation companies as many as 52 companies that have been certified ISPO/RSPO and ISO as well as other environmental certifications in North Sumatra Province as many as 125 samples, using a judgmental sample technique. Data collection was done by distributing questionnaires. After the questionnaires were distributed to the respondents, the data quality test was then conducted. The results of the test on the validity of the green-marketing variable instrument in the table:

\begin{tabular}{|l|l|}
\hline & Cronbach's Alpha \\
\hline X1 Green-marketing & 0.984 \\
\hline X2Positional Advantage & 0.935 \\
\hline Y Marketing Performance & 0.960 \\
\hline Z Green-innovational Value Creation & 0.921 \\
\hline
\end{tabular}

Table 3: Reliability Test based on Cronbach's Alpha

Table 3 above shows that the Composite Reliability (CR) value for each construct is $>0.7$, which means that it has met the reliability requirements based on the calculation of the Composite Reliability (CR) value.

$\mathrm{R}$ Square evaluation results. R-square can be used to evaluate the effect of certain independent latent variables on the dependent latent variable whether it has a substantive effect. The model is considered to have an effect if $R 2$ is greater than 0 (zero). The coefficient results of determination $\mathrm{R} 2$ from the model can be seen in the following table:

\begin{tabular}{|l|l|l|}
\hline & R Square & Adjusted R Square \\
\hline X2-Positional Advantage & 0.664 & 0.661 \\
\hline Y Marketing Performance & 0.872 & 0.869 \\
\hline Z Green-innovational Value Creation & 0.456 & 0.451 \\
\hline
\end{tabular}

Table 4. Research test results

Based on the results of the $R$ square test above, it is known as follows: Positional Advantage variable has a value of $R$ square $=0.664$ indicating that it has an influence of $66.4 \%$ on Marketing Performance. The Marketing Performance variable has a value of $R$ square $=0.872$ which indicates that it has an influence of $87.2 \%$. In addition, mediation analysis was also conducted showing a summary of the direct influence between the research variables above, presenting of the indirect influence the resultssummary of the variables in this study. The indirect effect of the Green-marketing variable on Marketing Performance (MP) through Positional Advantage is 0.414 . Next, the indirect effect of Green-marketing (GM) on Marketing Performance (MP) through Green-innovational Value Creation (GIVC) is 0.172 .

\section{Results And Discussion}

Furthermore, the t-value analysis results that have been conducted were also used as a reference to reject or accept the hypothesis. In this case, by using a significance level of $5 \%$ ( $\alpha=0.05$ ), and by using a confidence interval of $95 \%$, the minimum limit value of the $t$-value ( $t$-value) used was 1,96 . In this case, the hypothesis is rejected if the t-value is smaller than the minimum limit value that has been set, which is 1.96 (t-value 1.96). On the other hand, the hypothesis is accepted if the $t$-value is greater than the minimum limit value that has been set, which is 1.96 (t-value 1.96).

\section{Research Hypothesis Testing}

\begin{tabular}{|l|l|l|l|l|l|}
\hline Hypothesis & Statement & Coefficient & $\begin{array}{l}\text { T Statistics } \\
(\mid \mathbf{O} / \text { STDEV } \mid)\end{array}$ & P Values & Decision \\
\hline $\mathrm{H} 1$ & $\begin{array}{l}\text { Green-marketing gives a } \\
\text { good and substantial } \\
\text { impact on Marketing } \\
\text { Performance }\end{array}$ & 0.246 & 2.448 & 0.015 & $\begin{array}{l}\text { Hypothesis } \\
\text { accepted }\end{array}$ \\
\hline
\end{tabular}




\section{GENERAL MANAGEMENT}

\begin{tabular}{|c|c|c|c|c|c|}
\hline Hypothesis & Statement & Coefficient & $\begin{array}{l}\text { T } \quad \text { Statistics } \\
(\mid \text { O/STDEV } \mid)\end{array}$ & P Values & Decision \\
\hline H2 & $\begin{array}{l}\text { Green-marketing } \\
\text { variable gives a good } \\
\text { and substantial impact } \\
\text { on Positional Advantage }\end{array}$ & 0.822 & 17.783 & 0.000 & $\begin{array}{l}\text { Hypothesis } \\
\text { accepted }\end{array}$ \\
\hline H3 & $\begin{array}{l}\text { Green-marketing } \\
\text { variable gives a good } \\
\text { and substantial impact } \\
\text { on Green-innovational } \\
\text { Value Creation }\end{array}$ & 0.679 & 10.859 & 0.000 & $\begin{array}{l}\text { Hypothesis } \\
\text { accepted }\end{array}$ \\
\hline $\mathrm{H} 4$ & $\begin{array}{l}\text { Positional Advantage } \\
\text { variable gives a good } \\
\text { and substantial impact } \\
\text { on Marketing } \\
\text { Performance in the oil } \\
\text { palm plantation industry }\end{array}$ & 0.524 & 3.689 & 0.000 & $\begin{array}{l}\text { Hypothesis } \\
\text { accepted }\end{array}$ \\
\hline H5 & $\begin{array}{l}\text { The Green-innovation } \\
\text { Value Creation variable } \\
\text { gives a good and } \\
\text { substantial impact on } \\
\text { Marketing Performance }\end{array}$ & 0.240 & 3.233 & 0.001 & $\begin{array}{l}\text { Hypothesis } \\
\text { accepted }\end{array}$ \\
\hline $\mathrm{H} 6$ & $\begin{array}{l}\text { The Green-innovation } \\
\text { Value Creation variable } \\
\text { mediates the } \\
\text { relationship between } \\
\text { Green-marketing and } \\
\text { Marketing Performance } \\
\text { in the oil palm plantation } \\
\text { industry }\end{array}$ & 0.163 & 2.994 & 0.003 & $\begin{array}{l}\text { Hypothesis } \\
\text { accepted }\end{array}$ \\
\hline
\end{tabular}

The first hypothesis showed that the Green-marketing variable has a positive and substantial impact on Marketing Performance in the oil palm plantation industry, where the statistical value showed that the path coefficient calculation is 0.246 and the P-Values are $0.015>0.05$. The results confirmed that there is evidence to support the first hypothesis with the decision accepted. The more intense the application of green-marketing in the oil palm plantation industry has a relationship with increasing the marketing performance of the industry. Green-marketing will be increasingly in demand in the future in the oil palm plantation industry as the market demands an environmentally friendly process. This description may be a reference for the oil palm plantation industry in conducting its industrial activities (processes).

The second hypothesis stated that the Green-marketing Variable has a positive and substantial impact on Position Excellence in the oil palm plantation industry. The statistical value showed that the path coefficient for this hypothesis is 0.822 and the significance shows $P$-Values $0.000<0.05$. Statistically, these results support the first hypothesis with the conclusion that the hypothesis is acceptable. The application of green-marketing in the activities of the oil palm plantation industry will further enhance the competitive position of the oil palm plantation industry in the market. The plantation industry has an obligation to run its industrial business by respecting the environment. And this has been implemented by the palm oil plantation industry by implementing ISPO and ISO standards based on environmental management so the sustainable Indonesian oil palm plantations could be created. The better the product produced from the process to its quality, the more superior the company's position in its business activities. Eco-friendly products are increasingly in demand by consumers, especially in the palm oil industry which produces products such as chocolate, edible oil, butter to shampoo raw materials. Large companies in Indonesia (eg Unilever Indonesia) have made investments to increase their palm oil refining capacity. This goes along with the desire of Indonesia's Government which to generate more income from domestic natural resources. Indonesia has been focused (and dependent) on exports of crude palm oil (and other raw materials) but in recent years has pushed for the processing of natural resource products so that they have higher selling prices (which serve as a buffer when the palm oil prices slide). Refining capacity in Indonesia jumped to 45 million tons per year in early 2015, up from 30.7 million tons in 2013, and more than doubled 2012 capacity of 21.3 million tons. The description of activities in maintaining the quality of these products will further enhance the position of the palm oil industry in its business activities.

The third hypothesis stated that the green-marketing variable gives a good and substantial impact on the value creation of green-innovation. Statistical results showed that the path coefficient for this hypothesis is 0.679 and the significance shows P-Values $0.000<0.05$. Statistically, these results support the third hypothesis with the decision of the hypothesis being accepted. In supporting the creation of green-innovation values, the oil palm plantation industry applies the mandatory Indonesian Sustainable Palm Oil (ISPO). With the issuance of ISPO, Indonesia has declared its exit from the RSPO which is a monitoring group for sustainable practices on oil palm plantations issued by a group of importers/consumers of palm oil. With the issuance of ISPO, Indonesia officially has official and standard guidelines and regulations for sustainable palm oil plantations. This step is important not only for the implementation of sustainable production but is the beginning of Indonesia's palm oil diplomacy in the world market and creating a sustainable palm oil industry.

The fourth hypothesis stated that the position advantage 
variable gives a good and substantial impact on marketing performance in the oil palm plantation industry. Statistical results showed that the path coefficient for this hypothesis is 0.524 and the significance shows P-Values $0.000<0.05$. Statistically, these results support the fourth hypothesis with the decision of the hypothesis being accepted. The more superior the position of the oil palm plantation company in its industrial process activities will further improve the marketing performance of the oil palm plantation industry. Competitive advantage gives a good and substantial impact on marketing performance, in this case it also shows that increasing positional advantage will result in increased marketing performance in the oil palm plantation industry. The most dominant position advantage is reflected by the high dimensions of the availability of raw materials that use environmentally friendly materials.

The fifth hypothesis stated that the green-innovation value creation variable gives a good and substantial impact on marketing performance in the oil palm plantation industry. Statistical results showed that the path coefficient for this hypothesis is 0.143 and the significance shows $P$-Values 0.021 $<0.05$. Statistically, these results support the fifth hypothesis with the decision of the hypothesis being accepted. The creation of the value of green-innovation in the oil palm plantation industry affects marketing performance, for this reason the company is emphasized to maintain the quality of products that have been trusted by consumers, besides that companies are required to innovate on their special products to the process and creation of products based on eco- friendly products.

The sixth hypothesis stated that the green-innovation value creation variable mediates the effect of green-marketing by increasing marketing performance in the oil palm plantation industry. The test showed that green-innovation value creation mediates the effect of green-marketing and increasing marketing performance on the oil palm plantation industry, with path coefficient values of 0.163 and P-Values being $0.003<$ 0.05 . This means that the sixth hypothesis is statistically proven and accepted. Value creation in the process of the oil palm plantation industry is highly demanded to be improved considering that Indonesia is one of the largest producers of palm oil in the world along with Malaysia and other countries. Therefore, innovations that support environmentally friendly practices are increasingly needed in running the oil palm plantation business. Currently, Indonesia has established ISPO as one of the measuring tools for the national oil palm plantation industry process which has relevant principles for the management of oil palm plantations in the SDGs (sustainable development goals).

The importance of sustainable palm oil certification is to ensure that the process in the oil palm plantation industry pays attention to various environmental and social aspects to ensure its sustainability. At the present time, Indonesian palm oil has been hit by many black campaign issues because it is considered damaging to the environment and also its derivative products which are boycotted by European countries. Therefore, the Indonesian government in improving the quality of the oil palm plantation industry issues sustainable palm oil certification (ISPO) whose principles pay attention to environmental and social aspects and increase value creation in innovation. Overall, it can be concluded that all hypotheses formulated in this study are accepted, where this has been proven based on the results of data analysis, related literature, and the results of previous studies.

\section{Conclusion}

The tests conducted in this study on six hypotheses derived from the model between green-marketing variables, as independent variables, green-innovation value creation and position advantage as mediating variables and marketing performance as the dependent variable. From all the test results, these variables have a significant influence on the development of marketing performance in the oil palm plantation industry. Increasing the value of innovation (greeninnovation) in the palm oil plantation industry activities that are oriented to consumer demand based on technology improvements and $R \& D$ results.

\section{Implication}

Based on the results of the data analysis that these variables can identify various obstacles/problems faced in the oil palm plantation industry and can be used as a reference for improvement and improvement of company performance in the future. As well as overcoming obstacles to rejection of the high production yield of the domestic oil palm plantation industry more effectively, the oil palm plantation industry can be more selective in implementing the concept of green-marketing by producing eco-friendly innovations. In addition to this in the form of the basis policy makers in the oil palm plantation industry.

\section{Limitation and Suggestion}

The research limitations need to be conveyed in each research result because many things cannot be captured in the research model. Therefore, in this study, the limitations include: There are differences in the company's ability to apply the green-marketing concept in each company, this difference will have an impact on the diversity in respondents' answers to the application of the green-marketing concept. The results of this study cannot be generalized to other cases outside theresearch object. The type of industry can also affect the results of the study, including the different research periods can also affect the results. Limitations on statistical test results. The level of ability to explain research variables is still relatively moderate based on the squared multiple correlation (R2) test, which means that there is still potential for other variables to be determinants other than the variables in the model built.

The concept of green-marketing in industry was conducted in increasing industrial output and can improve the quality of product competition in the market. By implementing greenmarketing, it is hoped that the domestic oil palm plantation industry can compete in the global market. Some countries emphasize that they are free from environmental impacts for products that enter their country, so it is necessary for companies, especially oil palm plantations to implement greenmarketing in their industrial activities.Green-marketing strategies in the oil palm plantation industry need to be further improved to increase the competitive position of the palm oil industry, so that products from the oil palm plantation industry can be accepted among consumers. The oil palm plantation industries need to increase the value creation of innovations in its industrial processes, especially the creation of innovation values that lead to green-innovational value creation for the oil palm plantation industry. Those who support the sustainability of oil palm plantations that are economically viable, socially and culturally appropriate in accordance with the regulations. 


\section{References}

[1] Bidarian-Moniri, A., Nilsson, M., Attia, J., \& Ejnell, H. (2015). Mattress and pillow for prone positioning for treatment of obstructive sleep apnoea. Acta Oto-Laryngologica, 135(3), 271-276. doi:10.3109/00016489.2014.968674

[2] Asha'ari, M. J., \& Daud, S. (2017). The Effect of Green Growth Strategy on Corporate Sustainability Performance. Advanced Science Letters, 23(9), 8668-8674. doi:10.1166/asl.2017.9949

[3] Aslinda N. (2016), "The Mediating Effect of Green-innovation on The Relationship Between Green Supply Chain Management and Environmental Performance In Malaysia Manufacturing Industries",

[4] Babaoğul and Ozgun (2008).Strategic greenmarketing".Journal of Consumer Marketing (MCB UP Ltd) 10 (3).

[5] Banerjee, S. B. (2002). Corporate environmentalism: the construct and its measurement. Journal of Business Research, 55(3), 177-191. doi:10.1016/s01482963(00)00135-1

[6] Bhargava, M., N. Donthu and R. Caron (1994), 'Improving the Effectiveness of Outdoor Advertising: Lessons from a Study of 282 Campaigns', Journal of Advertising Research, 34 (2),4655.

[7] Calel, R., \& Dechezleprêtre, A. (2016). Environmental Policy and Directed Technological Change: Evidence from the European Carbon Market. Review of Economics and Statistics, 98(1), 173-191. doi:10.1162/rest_a_00470

[8] Chan, R. Y. K., He, H., Chan, H. K., \& Wang, W. Y. C. (2012). Environmental orientation and corporate performance: The mediation mechanism of green supply chain management and moderating effect of competitive intensity. Industrial Marketing Management, 41(4), 621-630. doi:10.1016/j.indmarman.2012.04.009

[9] Chang, C., \& Chen, Y. (2013). Green organizational identity and green innovation. Management Decision, 51(5), 10561070. doi:10.1108/md-09-2011-0314

[10] Chen, C.-C., Chen, C.-W., \& Tung, Y.-C. (2018). Exploring the Consumer Behavior of Intention to Purchase Green Products in Belt and Road Countries: An Empirical Analysis. Sustainability, 10(3), 854. doi:10.3390/su10030854.

[11] ChengedzaiMafini and Welby V. LouryOkoumba (2018).Extending Green Supply Chain Management Activities to Manufacturing Small and Medium Enterprises in Developing Economy, South African Journal of Economics and Management Sciences, 2018.

[12] ChipoMukonza and IlzeSwarts (2019) The influence of greenmarketing strategies on business performance and corporate image in the retail sector. Wiley Business Strategy and the Environment, Bus StratEnv. 1-8.

[13] Clark, B. H. and Ambler, T. (2001), "Marketing Performance Measurement: Evolution of Research and Practice", International Journal of Business Performance Management, Vol. 3, Winter, pp. 231-244.

[14] Pimenta da Gama, A. (2011). An expanded model of marketing performance. Marketing Intelligence \& Planning, 29(7), 643-661. doi:10.1108/02634501111178677

[15] Day, G. S., \& Wensley, R. (1988). Assessing Advantage: A Framework for Diagnosing Competitive Superiority. Journal of Marketing, 52(2), 1. doi:10.2307/1251261

[16] J. Dean, T., \& F. Pacheco, D. (2014). Green marketing: a strategic balancing act for creating value. Journal of Business Strategy, 35(5), 14-22. doi:10.1108/jbs-11-2013-0109

[17] Dechezleprêtre, A., Neumayer, E., \& Perkins, R. (2015). Environmental regulation and the cross-border diffusion of new technology: Evidence from automobile patents. Research Policy, 44(1), 244-257. doi:10.1016/j.respol.2014.07.017

[18] Durif, F, Boivin C and Julien C (2010).In Search of a Green Product Definition. Innovative Marketing Vol. 6(1): 25- 33.

[19] EvelyneVanpoucke, LievenQuintens and Merel Van Engelshoven (2016). The Role of Motivation in Relating Green Supply Chain Management to Performance, Supply Chain Management: An International Journal, 2016.

[20] Eneizan, BM and Wahab, K,A. (2016)," Effects of Greenmarketing Strategy on the Financial and Non-Financial Performance of Firms: A Conceptual Paper," Arabian Journal of Business and Management Review, Vol. 6 issuess 5.

[21] Fatoki, O (2019)," Green-marketing Orientation And Environmental And Social Performance Of Hospitality Firms In South Africa," Foundations of Management, Vol. 11.

[22] Flammer, C. (2013). Corporate Social Responsibility and Shareholder Reaction: The Environmental Awareness of Investors. Academy of Management Journal, 56(3), 758-781. doi:10.5465/amj.2011.0744

[23] Han, H., Yu, J., \& Kim, W. (2019).Environmental corporate social responsibility and the strategy to boost the airline's image and customer loyalty intentions.Journal of Travel \& Tourism Marketing, 36(3), 371-383.

[24] Hasan Z and Ali N.A (2014)," The Impact of green-marketing strategy on the firms Performance in Malaysia; ProcediaSocial and Behavioral Sciences, 172 pp. 463- 470.

[25] HelioRaymundo Ferreira Filho, LirhaFreitas Santos, Norma Ely Santos Beltrao (2016). A Study of Green Supply Chain Management: Analysis of GSCM Practices in Three Different Companies, WSEAS Transactions on Business and Economics, Vol. 13, 2016.

[26] Abdullah, M. H., Abdelmo'ti, S. A., \& Mahmoud, M. zyood. (2015). The Impact of the Application of Green Marketing Criteria on Marketing Performance. Greener Journal of Business and Management Studies, 5(1), 037-046. doi:10.15580/gjbms.2015.1.021615030

[27] Hoe, L. C., \& Mansori, S. (2018). The Effects of Product Quality on Customer Satisfaction and Loyalty: Evidence from Malaysian Engineering Industry. International Journal of Industrial Marketing, 3(1), 20. doi:10.5296/ijim.v3i1.13959

[28] HosseinNezakati, MeghdadAbbasianFereidouni and AzmawaniAbdRahman (2016), An Evaluation of Goverment Role in Green Supply Chain Management through Theories, International Journal of Economics and Financial Issues, 2016.

[29] Hunt, S.D and Morgan, R.M (1996), “ The Resource Advantage Theory of Competition: Dynamics, Path Dependencies and Evolutionary Dimensions", Journal of Marketing, Vol. 60, pp. 107-114

[30] Hunt, S. D. (1995). The Resource-Advantage Theory of Competition. Journal of Management Inquiry, 4(4), 317-332. doi:10.1177/105649269500400403

[31] Papadas, K.-K., Avlonitis, G. J., Carrigan, M., \& Piha, L. (2019). The interplay of strategic and internal green marketing orientation on competitive advantage. Journal of Business Research, 104, 632-643. doi:10.1016/j.jbusres.2018.07.009 